\title{
Note \\ Zincation of primary amines: synthesis and structures of dimeric alkylzinc amides
}

\author{
Matthias Westerhausen ${ }^{\mathrm{a}, *}$, Tobias Bollwein ${ }^{\mathrm{a}}$, Arno Pfitzner ${ }^{\mathrm{b}}$, Tom Nilges ${ }^{\mathrm{b}}$, \\ Hans-Jörg Deiseroth ${ }^{b}$ \\ ${ }^{a}$ Department Chemie, Ludwig-Maximilians-Universität München, Butenandtstrasse 9, (Haus D), D-81377 Munich, Germany \\ ${ }^{\mathrm{b}}$ Anorganische Chemie II, Universität Siegen, D-57068 Siegen, Germany
}

Received 5 July 2000; accepted 13 October 2000

\begin{abstract}
The zincation of triisopropylsilylamine with dimethyl- and diethylzinc yields dimeric methylzinc (1) and ethylzinc triisopropylsilylamide (2). Complex 1 crystallizes in the monoclinic space group $P 2_{1} / n, 2$ in $P 2_{1} / c$. The reaction of dimethylzinc with adamantylamine gives $[(\mathrm{THF}) \mathrm{ZnMe}]\left[\left(\mathrm{AdNH}_{2}\right) \mathrm{ZnMe}\right][\mu-\mathrm{N}(\mathrm{H}) \mathrm{Ad}]_{2}(\mathbf{3})$ which crystallizes in the monoclinic space group $P 2_{1} / n$. All these compounds have central $\mathrm{Zn}_{2} \mathrm{~N}_{2}$ cycles. Contrary to $\mathbf{1}$ and $\mathbf{2}$ with triply coordinated metal centers, the zinc atoms in $\mathbf{3}$ show a distorted tetrahedral coordination sphere due to the contact to the neutral coligands THF and adamantylamine. (C) 2001 Elsevier Science B.V. All rights reserved.
\end{abstract}

Keywords: Amides; Crystal structures; Metalations; Zinc complexes

\section{Introduction}

The zincation of secondary amines was already published in 1856 [1] and 1867 [2] by Frankland. Approximately 100 years later, the systematic investigations on the zinc amide chemistry began and numerous compounds of the type $\mathrm{R}^{\prime}-\mathrm{Zn}-\mathrm{NR}_{2}$ or $\mathrm{Zn}\left(\mathrm{NR}_{2}\right)_{2}$ were prepared thereafter [3]. Two reaction pathways allowed the synthesis of these compounds, namely the zincation of amines as well as the metathesis reaction of alkali metal amides with anhydrous zinc dihalide. Homoleptic zinc bis(amides) are well-known and their structures were determined [4].

The investigations on the zincation of primary amines are far less intensive and only a few alkylzinc amides were structurally characterized. The degree of oligomerization varies depending on the steric demand of the substituents at the zinc and nitrogen atoms. A

* Corresponding author. Tel.: + 49-89-218 07481; fax: +49-8921807867.

E-mail address: maw@cup.uni-muenchen.de (M. Westerhausen). monomer was observed for $\left(\mathrm{Me}_{3} \mathrm{Si}\right)_{3} \mathrm{CZn}-\mathrm{N}(\mathrm{H}) \mathrm{Si}^{i} \mathrm{Pr}_{3}$ [5], dimers form after the zincation of 2,4,6-trimethylaniline and 2,6-diisopropylaniline [6] whereas trimers were found after the reaction of diethylzinc with tertbutylamine [6] and naphthylamine [7]. To the authors' knowledge there are only very few reports on bis(alkylzincated) amines. Oguni and Tani [8] investigated the efficiency of bis(ethylzinc) tert-butylimide as a catalyst for stereospecific polymerization of propylene oxide. Kitsuno et al. [9] reported the use of bis(alkylzinc) trialkylsilylimides as precursors for the MOCVD process.

Imides with more electropositive metals such as magnesium were reported. The metalation of aniline [10] or naphthylamine [11] in THF with diethylmagnesium yielded the halide-free hexameric (tetrahydrofuran)magnesium phenylimide with a hexagonal $\mathrm{Mg}_{6} \mathrm{~N}_{6}$-prism. The dimeric pentamethylcyclopentadienylaluminium triisopropylsilylimide was not obtained by a metalation of a primary amine, but via the reaction of the tetrameric $\mathrm{Al}(\mathrm{I})$-derivative $\left[\mathrm{AlCp}^{*}\right]_{4}$ with triisopropylsilylazide [12]. 


\section{Experimental}

\subsection{General procedures}

All experiments and manipulations were carried out under an atmosphere of argon. Reactions were performed using standard Schlenk techniques and dried, thoroughly deoxygenated solvents. Triisopropylsilylamine was prepared by a literature procedure [13]. NMR spectra were recorded on JEOL spectrometers GSX270 and EX400. A Nicolet 520 FT-IR spectrophotometer was used to record the IR spectra; solid substances were measured in Nujol between $\mathrm{KBr}$ plates (vs very strong, s strong, $\mathrm{m}$ medium strong, $\mathrm{w}$ weak, $\mathrm{vw}$ very weak, sh shoulder). The low carbon and nitrogen values at the elemental analysis result from carbide and carbonate as well as nitride formation during combustion of the compounds.

\subsection{Synthesis of dimeric methylzinc triisopropylsilylamide (1)}

To a solution of $3.0 \mathrm{ml}$ of triisopropylsilylamine $(2.47$ $\mathrm{g}, 14.3 \mathrm{mmol}$ ) in $5 \mathrm{ml}$ of toluene $7.15 \mathrm{ml}$ of a $2.0 \mathrm{M}$ solution of dimethylzinc $(14.3 \mathrm{mmol})$ in toluene was added. After $10 \mathrm{~h}$ at room temperature (r.t.) the solution was heated under reflux for additional $2 \mathrm{~h}$. After reduction of the volume to approximately $3 \mathrm{ml}, 1.34 \mathrm{~g}$ of colorless $1(2.65 \mathrm{mmol}, 37 \%)$ crystallized; m.p. $94^{\circ} \mathrm{C}$. NMR data: ${ }^{1} \mathrm{H}$ (toluene- $\left.\mathrm{d}_{8}\right): \delta 1.07\left[\mathrm{~d},{ }^{3} J(\mathrm{H}, \mathrm{H})=7.3\right.$ $\mathrm{Hz}, 18 \mathrm{H}, \mathrm{CH}_{3}$ ], 0.98 [sept., ${ }^{3} J(\mathrm{H}, \mathrm{H})=7.3 \mathrm{~Hz}, 3 \mathrm{H}, \mathrm{CH}$ ], -0.24 (s, 3H, ZnMe), $-0.77(\mathrm{br}, 1 \mathrm{H}, \mathrm{NH}) .{ }^{13} \mathrm{C}\left\{{ }^{1} \mathrm{H}\right\}$ (toluene- $\left.\mathrm{d}_{8}\right): \quad \delta \quad 18.68 \quad\left(\mathrm{CH}_{3}\right), \quad 13.17 \quad(\mathrm{CH}), \quad-8.97$ (ZnMe). ${ }^{29} \mathrm{Si}\left\{{ }^{1} \mathrm{H}\right\} \quad$ (toluene- $\left.\mathrm{d}_{8}\right): \delta$ 12.06. IR $\left(\mathrm{cm}^{-1}\right)$ : $3482 \mathrm{vw}, 3403 \mathrm{vw}, 3278 \mathrm{w}, 2752 \mathrm{vw}, 2725 \mathrm{vw}, 2711 \mathrm{vw}$, $2300 \mathrm{vw}, 1544 \mathrm{vw}, 1462 \mathrm{~s}, 1385 \mathrm{~m}, 1365 \mathrm{~m}, 1289 \mathrm{vw}$, $1255 \mathrm{w}, 1246 \mathrm{sh}, 1163 \mathrm{w}, 1072 \mathrm{w}, 1059 \mathrm{vw}, 1015 \mathrm{vs}, 993$ sh, 978 sh, 918 w, 881 vs, 813 sh, 788 vs, 690 vs, 661 s, $632 \mathrm{sh}, 540 \mathrm{~m}, 503 \mathrm{~m} 489 \mathrm{vw}, 468 \mathrm{~m}, 304 \mathrm{vw}, 278 \mathrm{vw}$. MS (EI): $131(11 \%), 130\left(\mathrm{H}_{2} \mathrm{NSi}^{i} \mathrm{Pr}_{3}-{ }^{i} \mathrm{Pr}, 100 \%\right), 102$ $\left(130-\mathrm{C}_{2} \mathrm{H}_{4}, 29 \%\right), 88(15 \%), 74(25 \%), 60(47 \%), 46$ (5\%), $44(16 \%) ; 41(7 \%), 39$ (5\%). Anal. Found: $\left(\left[\mathrm{C}_{10} \mathrm{H}_{25} \mathrm{NSiZn}\right]_{2}\right):$ Calc. C, 47.51; H, 9.97; N, 5.54; Found C, 47.49; H, 9.97; N, 5.51\%.

\subsection{Synthesis of dimeric ethylzinc triisopropylsilylamide (2)}

To a solution of $3.0 \mathrm{ml}$ triisopropylsilylamine (14.3 mmol) in $5 \mathrm{ml}$ toluene $14.3 \mathrm{ml}$ of a $1.0 \mathrm{M}$ diethylether solution of diethylzinc was added. After refluxing for 3 $\mathrm{h}$ all volatile materials were removed under vacuum at r.t. The yellow residue was recrystallized from $2 \mathrm{ml}$ of toluene and $1.83 \mathrm{~g}$ of colorless needles of $2(3.43 \mathrm{mmol}$, $48 \%$ ) were isolated; m.p. $71^{\circ} \mathrm{C}$. NMR data: ${ }^{1} \mathrm{H}$ (benzene- $\left.\mathrm{d}_{6}\right): \delta 1.52\left[\mathrm{t},{ }^{3} \mathrm{~J}(\mathrm{H}, \mathrm{H})=8.0 \mathrm{~Hz}, 3 \mathrm{H}, \mathrm{CH}_{3} \mathrm{CH}_{2} \mathrm{Zn}\right]$, $1.08\left[\mathrm{~d},{ }^{3} J(\mathrm{H}, \mathrm{H})=7.2 \mathrm{~Hz}, 18 \mathrm{H}, \mathrm{CH}_{3}\left({ }^{i} \mathrm{Pr}\right)\right], 1.02$ [sept, $\left.{ }^{3} J(\mathrm{H}, \mathrm{H})=7.2 \mathrm{~Hz}, 3 \mathrm{H}, \mathrm{CH}\right], 0.62\left[\mathrm{q},{ }^{3} J(\mathrm{H}, \mathrm{H})=8.0 \mathrm{~Hz}\right.$, $\left.2 \mathrm{H}, \mathrm{CH}_{3} \mathrm{CH}_{2} \mathrm{Zn}\right],-0.69$ (br, $\left.1 \mathrm{H}, \mathrm{NH}\right) .{ }^{13} \mathrm{C}\left\{{ }^{1} \mathrm{H}\right\}$ (benzene- $\left.\mathrm{d}_{6}\right): \quad \delta \quad 18.70 \quad\left[\mathrm{CH}_{3}\left({ }^{i} \mathrm{Pr}\right)\right], \quad 13.38 \quad(\mathrm{CH}), \quad 12.50$ $\left(\mathrm{CH}_{3} \mathrm{CH}_{2} \mathrm{Zn}\right), 4.55\left(\mathrm{CH}_{3} \mathrm{CH}_{2} \mathrm{Zn}\right) .{ }^{29} \mathrm{Si}\left\{{ }^{1} \mathrm{H}\right\}$ (benzene$\left.\mathrm{d}_{6}\right): \delta$ 11.90. IR $\left(\mathrm{cm}^{-1}\right): 3484 \mathrm{vw}, 3403 \mathrm{vw}, 3279 \mathrm{vw}$, $2753 \mathrm{vw}, 2720 \mathrm{vw}, 1654 \mathrm{vw}, 1558$ sh, $1544 \mathrm{w}, 1463 \mathrm{vs,}$ $1416 \mathrm{vw}, 1382 \mathrm{~m}, 1366 \mathrm{w}, 1290 \mathrm{vw}, 1257 \mathrm{w}, 1246 \mathrm{sh}$, $1232 \mathrm{vw}, 1172 \mathrm{vw}, 1159 \mathrm{vw}, 1096 \mathrm{vw}, 1072 \mathrm{sh}, 1059 \mathrm{sh}$, 1046 sh, 1015 vs, 993 sh, 956 vw, 918 w, 883 vs, 818 sh, 786 vs, 729 w, $690 \mathrm{~s}, 664 \mathrm{~m}, 648 \mathrm{~m}, 632 \mathrm{~s}, 512 \mathrm{~m}, 506$ $\mathrm{m}, 490 \mathrm{w}, 463 \mathrm{~m}, 420$ vw. MS (EI): $131(12 \%), 130$ $\left(\mathrm{H}_{2} \mathrm{NSi}^{i} \mathrm{Pr}_{3}-{ }^{i} \mathrm{Pr}, \quad 100 \%\right), \quad 102 \quad\left(130-\mathrm{C}_{2} \mathrm{H}_{4}, 32 \%\right), 92$ (24\%), 91 (36\%), 88 (15\%), $74(25 \%), 60(36 \%), 44$ (14\%). Anal. Found: $\left(\left[\mathrm{C}_{11} \mathrm{H}_{27} \mathrm{NSiZn}\right]_{2}\right)$ : Calc. C, 49.52; H, 10.20; N, 5.25; Found C, 47.26; H, 10.23; N, 4.96\%.

\subsection{Synthesis of (tetrahydrofuran)methylzinc (adamantylamine)methylzinc bis( $\mu$-triisopropylsilylamide) (3)}

A $2.0 \mathrm{M}$ solution of dimethylzinc in toluene $(3.1 \mathrm{ml}$, $6.2 \mathrm{mmol}$ ) was dropped to a solution of $0.95 \mathrm{ml}$ 1-adamantylamine $(6.3 \mathrm{mmol})$ dissolved in $10 \mathrm{ml}$ of toluene. After stirring for an additional hour at r.t., all volatile materials were removed in vacuo at r.t. The residue was recrystallized from THF and at $-20^{\circ} \mathrm{C}$, $0.89 \mathrm{~g}$ of colorless $3(1.3 \mathrm{mmol}, 62 \%)$ were collected, m.p. $>300^{\circ} \mathrm{C}$. NMR data: ${ }^{1} \mathrm{H}$ (benzene- $\left.\mathrm{d}_{6}\right): \delta 3.57(\mathrm{~m}$, thf), 1.95 [br, $\mathrm{CH}(\mathrm{Ad})], 1.53$ [br, $\left.\mathrm{CH}_{2}(\mathrm{Ad})\right], 1.41$ (m, thf), 0.77 (s, ZnMe), -0.09 (s, ZnMe), $\mathrm{NH}$ and $\mathrm{NH}_{2}$ not observed. ${ }^{13} \mathrm{C}\left\{{ }^{1} \mathrm{H}\right\}$ (benzene- $\left.\mathrm{d}_{6}\right): \delta 67.56$ (thf), 47.35 [C $\left.\mathrm{C}_{\mathrm{q}}(\mathrm{Ad})\right], 46.25$ (Ad), 36.38 (Ad), 30.02 (Ad), 25.56 (thf), -0.77 (ZnMe), - 6.73 (ZnMe). IR (Nujol, $\left.\left[\mathrm{cm}^{-1}\right]\right): 3304 \mathrm{~m}, 3260 \mathrm{~m}, 3165 \mathrm{vw}, 1596 \mathrm{~m}, 1473 \mathrm{w}$, 1449 s, 1385 vw, $1360 \mathrm{w}, 1347 \mathrm{~m}, 1330 \mathrm{w}, 1312 \mathrm{w}, 1302$ m, $1291 \mathrm{vw}, 1283 \mathrm{vw}, 1273 \mathrm{w}, 1208 \mathrm{vw}, 1192 \mathrm{w}, 1181$ vw, 1153 vw, 1129 vs, 1093 s, 1071 s, 1043 s, 1034 s, 987 w, $977 \mathrm{w}, 964 \mathrm{vw}, 933 \mathrm{~s}, 915 \mathrm{vw}, 884 \mathrm{w}, 826 \mathrm{vw}, 813 \mathrm{~m}$, $799 \mathrm{vw}, 778 \mathrm{vw}, 741 \mathrm{~s}, 719 \mathrm{~m}, 640 \mathrm{~s}, 584 \mathrm{~m}, 564 \mathrm{vw}, 531$ m, $516 \mathrm{w}, 507 \mathrm{~m}, 496 \mathrm{~m}, 443 \mathrm{w}$. MS (EI): $429(19 \%)$, $355(32 \%), 341(25 \%), 281(88 \%), 267(27 \%), 209(43 \%)$, $208(68 \%), 207(100 \%), 193(26 \%), 177(30 \%), 151$ (23\%), $94 \quad(100 \%), \quad 79 \quad(55 \%)$. Anal. Found: $\left(\mathrm{C}_{36} \mathrm{H}_{63} \mathrm{~N}_{3} \mathrm{OZn}_{2}\right)$ : Calc. C, 63.15; H, 9.28; N, 6.14; Found C, 62.30; H, 9.00; N, 5.98\%.

\subsection{Crystal structure determinations}

Data was collected on a STOE-IPDS diffractometer with graphite monochromated Mo $\mathrm{K} \alpha$ radiation $(\lambda=$ $71.073 \mathrm{pm}$ ) using oil-coated rapidly cooled single crystals. Crystallographic parameters, details of data collection and refinement procedures are summarized in Table 1. 
All structures were solved by direct methods and refined with the software packages SHELXL-93 and SHELXL-97 [15]. Neutral scattering factors were taken from Cromer and Mann [16] and for the hydrogen atoms from Stewart et al. [17]. The non-hydrogen atoms were refined anisotropically. The asymmetric units of $\mathbf{1}$ and $\mathbf{2}$ contain two half molecules (monomers) which are completed by inversion symmetry. The $\mathrm{H}$-atoms of $\mathbf{1}$ and $\mathbf{2}$ were considered with a riding model under restriction of ideal symmetry at the corresponding carbon atoms. The $\mathrm{N}$-bonded hydrogen atoms of $\mathbf{1}$ and $\mathbf{2}$, the $\mathrm{H}$-atoms of the isopropyl $\mathrm{CH}$ fragments of $\mathbf{1}$ as well as all hydrogen atoms of $\mathbf{3}$ were refined isotropically without any restrictions.

Table 1

Crystallographic data of $\mathbf{1}, \mathbf{2}$ and $\mathbf{3}$ as well as details of the structure solution and refinement procedures

\begin{tabular}{|c|c|c|c|}
\hline Compound & 1 & 2 & 3 \\
\hline $\begin{array}{r}\text { Empirical } \\
\text { formula }\end{array}$ & $\mathrm{C}_{20} \mathrm{H}_{50} \mathrm{~N}_{2} \mathrm{Si}_{2} \mathrm{Zn}_{2}$ & $\mathrm{C}_{22} \mathrm{H}_{54} \mathrm{~N}_{2} \mathrm{Si}_{2} \mathrm{Zn}_{2}$ & $\mathrm{C}_{36} \mathrm{H}_{63} \mathrm{~N}_{3} \mathrm{OZn}_{2}$ \\
\hline $\begin{array}{l}\text { Molecular mass } \\
\left(\mathrm{g} \cdot \mathrm{mol}^{-1}\right)\end{array}$ & 505.54 & 533.59 & 684.63 \\
\hline Temp. $T(\mathrm{~K})$ & 173 & 173 & 173 \\
\hline Crystal system & monoclinic & monoclinic & monoclinic \\
\hline $\begin{array}{l}\text { Space group } \\
{[14]}\end{array}$ & $P 2_{1} / n$ (no. 14$)$ & $P 2_{1} / c$ (no. 14$)$ & $P 2_{1} / n$ (no. 14$)$ \\
\hline \multicolumn{4}{|c|}{ Unit cell dimensions } \\
\hline$a(\AA)$ & $15.440(3)$ & $16.5421(8)$ & $16.140(1)$ \\
\hline$b(\AA)$ & $11.200(2)$ & $11.3273(7)$ & $12.8029(6)$ \\
\hline$c(\AA)$ & $16.630(3)$ & $16.6044(9)$ & $16.788(1)$ \\
\hline$\beta\left(^{\circ}\right)$ & $107.50(3)$ & $111.78(3)$ & $93.346(8)$ \\
\hline$V\left(\AA^{3}\right)$ & $2742.7(9)$ & $2889.3(3)$ & $3463.1(4)$ \\
\hline$Z$ & 4 & 4 & 4 \\
\hline$\rho_{\text {calcd }}\left(\mathrm{g} \cdot \mathrm{cm}^{3}\right)$ & 1.224 & 1.227 & 1.313 \\
\hline$\lambda(\AA)$ & 0.71069 & 0.71069 & 0.71069 \\
\hline$\mu\left(\mathrm{cm}^{-1}\right)$ & 1.844 & 1.754 & 1.417 \\
\hline Scan range $\left(^{\circ}\right)$ & $5.6<2 \theta<56.3$ & $4.4<2 \theta<51.7$ & $4.6<2 \theta<56.1$ \\
\hline Measured data & 47253 & 17722 & 31770 \\
\hline $\begin{array}{l}\text { Unique data } \\
\left(R_{\text {int }}\right)\end{array}$ & $6263(0.0792)$ & $5343(0.1046)$ & $8300(0.0453)$ \\
\hline Parameters & 267 & 261 & 632 \\
\hline $\begin{array}{l}w R_{2}{ }^{a} \text { (all data, } \\
\text { on } F^{2} \text { ) }\end{array}$ & 0.1381 & 0.1475 & 0.0707 \\
\hline$R_{1}{ }^{\text {a }}$ (all data) & 0.0568 & 0.0616 & 0.0383 \\
\hline $\begin{array}{l}\text { Observed data } \\
\qquad[I>2 \sigma(I)]\end{array}$ & 5256 & 4256 & 6614 \\
\hline$R_{1}{ }^{\mathrm{a}}[I>2 \sigma(I)]$ & 0.0499 & 0.0506 & 0.0277 \\
\hline $\begin{array}{l}\text { Goodness-of-fits } \\
\text { b on } F^{2}\end{array}$ & 1.030 & 1.056 & 0.986 \\
\hline $\begin{array}{l}\text { Residual } \\
\text { density } \\
\left(\mathrm{e} \cdot \AA^{-3}\right)\end{array}$ & $1.154 /-1.509$ & $0.993 /-0.924$ & $0.410 /-0.415$ \\
\hline CCDC-number & 146588 & 146589 & 146590 \\
\hline
\end{tabular}

\footnotetext{
${ }^{\text {a }}$ Definition of the $R$ indices: $R_{1}=\left(\Sigma|| F_{\mathrm{o}}|-| F_{\mathrm{c}} \mid\right) / \Sigma\left|F_{\mathrm{o}}\right| . \quad w R_{2}=$ $\left\{\Sigma\left[w\left(F_{\mathrm{o}}^{2}-F_{\mathrm{c}}^{2}\right)^{2}\right] / \Sigma\left[w\left(F_{\mathrm{o}}^{2}\right)^{2}\right]\right\}^{1 / 2}$ with $w^{-1}=\sigma^{2}\left(F_{\mathrm{o}}^{2}\right)+(a P)^{2}$. ${ }^{\mathrm{b}} s=\left\{\Sigma\left[w\left(F_{\mathrm{o}}^{2}-F_{\mathrm{c}}^{2}\right)^{2}\right] /\left(N_{\mathrm{o}}-N_{\mathrm{p}}\right)\right\}^{1 / 2}$.
}

\section{Results and discussion}

\subsection{Synthesis}

The metalation of triisopropylsilylamine with dimethylzinc and diethylzinc yields dimeric methyl- (1) and ethylzinc triisopropylsilylamide (2). The intramolecular elimination of alkane and the formation of a zinc imide was not observed even in boiling toluene (Eq. (1)). In contrast to the low reactivity of this amine the homologous phosphane [18,19] and arsane [5] are easily twice alkylzincated at r.t. by the reaction of $\mathrm{RZnCl}$ with $\mathrm{LiE}(\mathrm{H}) \mathrm{Si}^{i} \operatorname{Pr}_{3}(\mathrm{E}=\mathrm{P}, \mathrm{As})$.

$$
2 \mathrm{ZnR}_{2}+2 \mathrm{H}_{2} \mathrm{~N}-\mathrm{Si}^{\mathrm{i}} \mathrm{Pr}_{3} \rightarrow\left[\mathrm{RZn}-\mathrm{N}(\mathrm{H}) \mathrm{Si}^{\mathrm{i}} \mathrm{Pr}_{3}\right]_{2}+2 \mathrm{RH}
$$

$\mathrm{R}=\mathrm{Me}(\mathbf{1})$, Et (2)

Zincation of adamantylamine with dimethylzinc leads to a colorless solution. After a few minutes a colorless solid precipitates which dissolves readily in THF. Recrystallization from THF gives the colorless complex 3 according to Eq. (2).

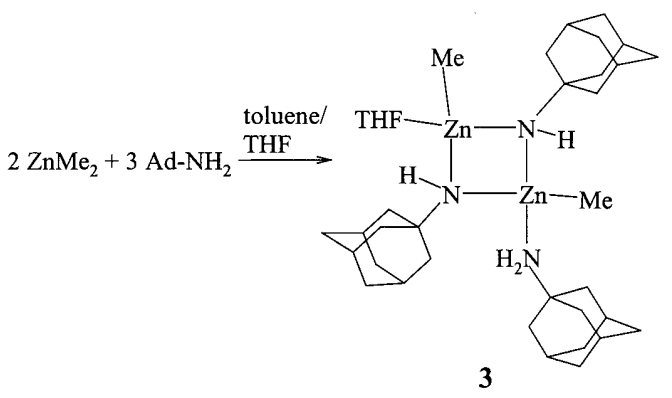

A stoichiometry of $1 / 1$ for the ratio of $\mathrm{ZnMe}_{2}-\mathrm{Ad}$ $\mathrm{NH}_{2}$ also gives complex 3. Dimethylzinc is neither able to metalate the amide substituents nor the coordinated amine ligand. Furthermore, the formation of zinc bis(adamantylamide) from 3 by intramolecular metalation or via dismutation reactions was not observed. Thus, this molecule explicitly depicts the reduction of reactivity of the zinc-bonded methyl groups and of the $\mathrm{NH}$-groups of the amide substituents as well as the coordinated amine ligands. Contrary to the investigations the straightforward preparation of bis(alkylzinc) tert-butylamine by metalation of $\mathrm{H}_{2} \mathrm{~N}-{ }^{t} \mathrm{Bu}$ by dialkylzinc was reported $[8,9]$.

The zincation of adamantylamine has nearly no influence on the chemical shifts of the ${ }^{1} \mathrm{H}$ as well as ${ }^{13} \mathrm{C}$ nuclei. The coordination of an adamantylamine to a metal center has been concluded from the elemental analysis. The confirmation was furnished by a crystal structure determination of $\mathbf{3}$. 


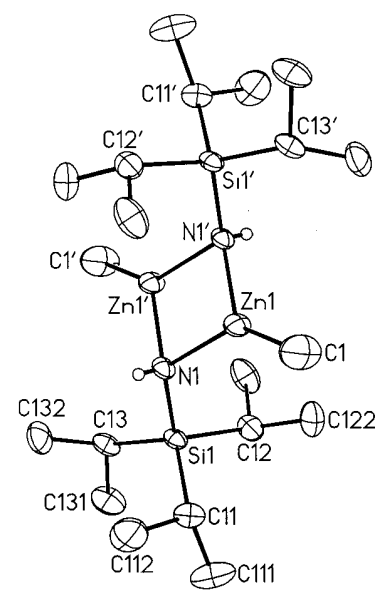

Fig. 1. Molecular structure and numbering scheme of 1. The ellipsoids represent a probability of $40 \%$. The $\mathrm{N}$-bonded $\mathrm{H}$ atoms are shown with arbitrary radii, whereas all other hydrogen atoms are omitted for clarity reasons. Atoms generated by inversion symmetry are marked with apostrophes.

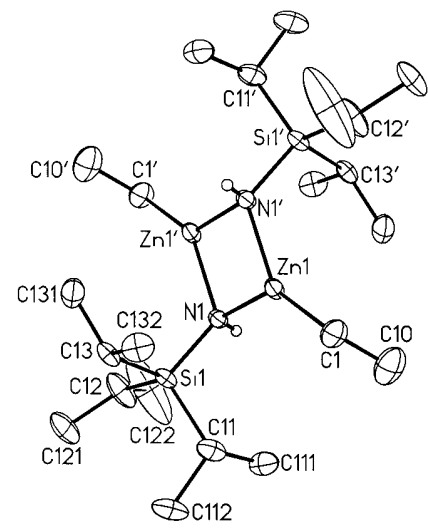

Fig. 2. Molecular structure and numbering scheme of 2. The presentation is similar to Fig. 1.

\subsection{Structural studies of $\mathbf{1}$ and $\mathbf{2}$}

Complexes $\mathbf{1}$ and $\mathbf{2}$ crystallize in monoclinic space groups with two crystallographically independent molecule halves in the asymmetric unit. Both the molecules are completed by crystallographical inversion symmetry. The first digit $n$ after the atom symbol distinguishes between the molecules 1 and 2. Only the molecular structures of the molecules with $n=1$ of $\mathbf{1}$ and $\mathbf{2}$ and their numbering schemes are represented in Figs. 1 and 2. Selected bond lengths and angles are given in Table 2 .

The central planar $\mathrm{Zn}_{2} \mathrm{~N}_{2}$ cycles show with nearly rectangular angles only insignificant deviations from a square. The coordination spheres of the zinc atoms are planar and the bond lengths lie in characteristic regions $[6,20]$. The nitrogen atoms are surrounded slightly dis- torted tetrahedrally with $\mathrm{N}-\mathrm{Si}$ distances of approximately $174 \mathrm{pm}$ which are insignificantly larger than in $\left[\mathrm{Cp} * \mathrm{Al}-\mathrm{NSi}^{i} \mathrm{Pr}_{3}\right]_{2}$ (173.0(2) pm [12]) with triply coordinated $\mathrm{N}$ atoms. All these structural parameters exclude intramolecular steric strain and it is even more surprising, that it is impossible to zincate the $\mathrm{NH}$ moieties once more to form an imide.

\subsection{Molecular structure of $\mathbf{3}$}

The molecular structure and selected structural parameters of $\mathbf{3}$ as well as the numbering scheme are given in Fig. 3. This molecule shows a transannular cis arrangement due to steric reasons. The higher coordination number of four at the metal centers leads to $\mathrm{Zn}-\mathrm{C}$ bond lengths of approximately $199 \mathrm{pm}$. The coordination spheres of both the zinc atoms are different: one metal center is bonded to a tetrahydrofuran molecule ( $\mathrm{Zn} 2)$, the other one to an adamantylamine coligand $(\mathrm{Zn} 1)$. Due to that fact, the $\mathrm{Zn}-\mathrm{N}$ distances differ of approximately $4 \mathrm{pm}$.

The $\mathrm{Zn} 2-\mathrm{O} 6$ distance of 240.1(1) pm is extremely large. In similar ethylzinc amides such as $[\mathrm{EtZn}(\mathrm{NHMes})(\mathrm{THF})]_{2} \quad(224$ and $232 \mathrm{pm}$ [6]) or $[\mathrm{EtZnN}(\mathrm{H}) \text { naphthyl(THF) }]_{3}$ [21] smaller $\mathrm{Zn}-\mathrm{O}$ bond lengths were observed. In monomeric bis(tetrahydrofuran)zinc bis(diphenylamide) zinc-oxygen distances of approximately $210 \mathrm{pm}$ were found [22]. This loose contact between zinc and the THF ligand leads to a very small deviation from planarity for the $\mathrm{ZnN}_{2} \mathrm{C}$ fragment (angle sum at $\mathrm{Zn} 2357.1^{\circ}$ ). The adamantylamine molecule shows a $\mathrm{Zn1-N5}$ distance of 220.4(1)

Table 2

Selected bond lengths (pm) and angles $\left(^{\circ}\right)$ of $\mathbf{1}$ and $\mathbf{2}^{\text {a }}$

\begin{tabular}{|c|c|c|c|c|}
\hline & \multicolumn{2}{|c|}{1} & \multicolumn{2}{|l|}{2} \\
\hline & Molecule 1 & Molecule 2 & Molecule 1 & Molecule 2 \\
\hline $\mathrm{Zn}(\mathrm{n})-\mathrm{C}(\mathrm{n})$ & 194.3(3) & 194.4(3) & 196.4(4) & 196.2(4) \\
\hline $\mathrm{Zn}(\mathrm{n})-\mathrm{N}(\mathrm{n})$ & $201.5(2)$ & $202.2(2)$ & $204.5(3)$ & $204.2(3)$ \\
\hline $\mathrm{Zn}(\mathrm{n})-\mathrm{N}(\mathrm{n})^{\prime}$ & $204.0(2)$ & $203.4(2)$ & $201.5(3)$ & $201.1(3)$ \\
\hline$N(n)-S i(n)$ & $173.8(2)$ & $173.8(2)$ & $174.3(3)$ & 174.1(3) \\
\hline $\mathrm{N}(\mathrm{n})-\mathrm{H}(\mathrm{n})$ & $61(4)$ & $79(4)$ & $74(5)$ & $85(4)$ \\
\hline $\operatorname{Si}(\mathrm{n})-\mathrm{C}(\mathrm{n} 1)$ & $189.3(3)$ & $189.2(2)$ & $189.0(4)$ & $187.7(4)$ \\
\hline $\operatorname{Si}(\mathrm{n})-\mathrm{C}(\mathrm{n} 2)$ & 189.1(3) & $188.6(2)$ & $188.7(4)$ & $188.8(4)$ \\
\hline $\operatorname{Si}(\mathrm{n})-\mathrm{C}(\mathrm{n} 3)$ & $188.6(2)$ & $188.7(2)$ & $188.2(4)$ & 189.4(4) \\
\hline $\mathrm{C}(\mathrm{n})-\mathrm{Zn}(\mathrm{n})-\mathrm{N}(\mathrm{n})$ & $136.8(1)$ & $135.8(1)$ & $136.7(2)$ & $130.9(2)$ \\
\hline $\mathrm{C}(\mathrm{n})-\mathrm{Zn}(\mathrm{n})-\mathrm{N}(\mathrm{n})^{\prime}$ & $133.1(1)$ & $134.4(1)$ & $133.6(2)$ & $139.3(2)$ \\
\hline $\mathrm{N}(\mathrm{n})-\mathrm{Zn}(\mathrm{n})-\mathrm{N}(\mathrm{n})^{\prime}$ & $89.95(8)$ & $89.77(7)$ & 89.7(1) & $89.7(1)$ \\
\hline $\mathrm{Zn}(\mathrm{n})-\mathrm{N}(\mathrm{n})-\mathrm{Si}(\mathrm{n})$ & $123.6(1)$ & $121.0(1)$ & $118.1(2)$ & $117.8(2)$ \\
\hline $\mathrm{Zn}(\mathrm{n})^{\prime}-\mathrm{N}(\mathrm{n})-\mathrm{Si}(\mathrm{n})$ & $118.6(1)$ & $120.1(1)$ & $122.6(2)$ & $123.4(2)$ \\
\hline $\mathrm{Zn}(\mathrm{n})-\mathrm{N}(\mathrm{n})-\mathrm{Zn}(\mathrm{n})^{\prime}$ & $90.05(8)$ & $90.23(7)$ & $90.3(1)$ & $90.3(1)$ \\
\hline $\mathrm{Zn}(\mathrm{n})-\mathrm{N}(\mathrm{n})-\mathrm{H}(\mathrm{n})$ & $110(4)$ & $114(3)$ & $111(4)$ & $113(3)$ \\
\hline $\mathrm{Zn}(\mathrm{n})^{\prime}-\mathrm{N}(\mathrm{n})-\mathrm{H}(\mathrm{n})$ & $110(4)$ & $103(3)$ & $111(4)$ & $110(3)$ \\
\hline $\mathrm{Si}(\mathrm{n})-\mathrm{N}(\mathrm{n})-\mathrm{H}(\mathrm{n})$ & $104(4)$ & $107(3)$ & $103(4)$ & $102(3)$ \\
\hline
\end{tabular}

a Atoms generated by crystallographic inversion symmetry are marked with apostrophes. 


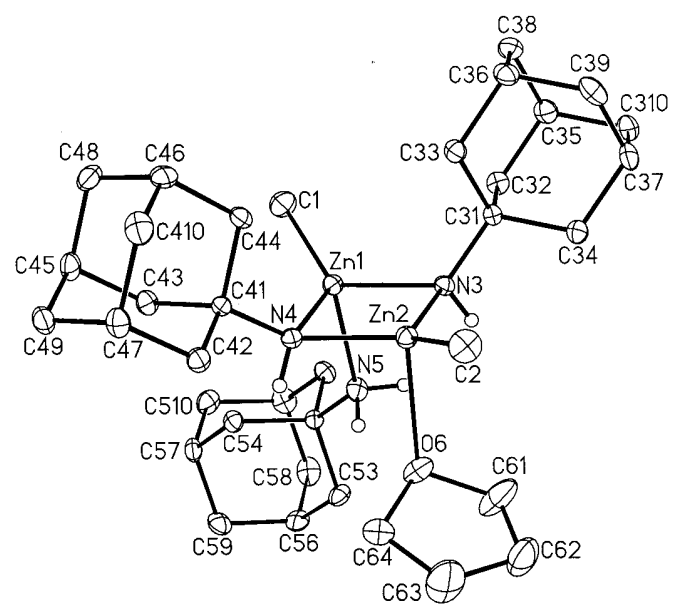

Fig. 3. Molecular structure and numbering scheme of 3. The ellipsoids represent a probability of $40 \%$. The $\mathrm{N}$-bonded $\mathrm{H}$ atoms are shown with arbitrary radii, whereas all other hydrogen atoms are omitted for clarity reasons. Selected bond lengths (pm): $\mathrm{Zn} 1-\mathrm{C} 1$ 199.8(2), Zn1-N3 207.3(1), Zn1-N4 208.0(1), Zn1-N5 220.4(1), Zn2-C2 198.3(2), Zn2-N3 204.0(1), Zn2-N4 203.9(1), Zn2-O6 240.1(1), N3-C31 147.3(2), N4-C41 146.9(2), N5-C51 148.2(2); angles $\left({ }^{\circ}\right)$ : N3-Zn1-N4 89.40(5), Zn1-N4-Zn2 89.47(5), N4-Zn2N3 91.47(5), Zn1-N3-Zn2 89.64(5), C1-Zn1-N3 127.83(6), C1Zn1-N4 126.65(7), C2-Zn2-N3 129.27(7), C2-Zn2-N4 136.31(7).

pm which lies in the characteristic region for amine adducts of compounds with a quadruply coordinated zinc center [23,24]. Therefore, the angle sum of $\mathrm{Zn} 1$ under neglection of N5 amounts $343.9^{\circ}$ and confirms the distorted tetrahedral coordination sphere of this metal center.

\section{Conclusions}

Zincation reactions of primary amines yield quantitatively heteroleptic alkylzinc amides. The reactivity of the zinc-bonded alkyl groups as well as of the remaining NH-moieties are strongly reduced and a further metalation was not observed. As of yet, imides could not be obtained from simple zincation reactions even in boiling toluene. This fact is in agreement with the observations of Power and coworkers [6] at zincated aryl- and alkylamines. The trialkylsilyl substitution does not enhance the reactivity of the $\mathrm{NH}$ moieties compared to alkyl or aryl substituted amines.

The advantage of the metalation in comparison to the metathesis reaction of a lithium amide with anhydrous zinc dihalide is the avoidance of the formation of lithium halides. These lithium salts do not precipitate quantitatively or even form lithium zincates of the type $\mathrm{Li}^{+}\left[\mathrm{ZnXR}_{2}\right]^{-}[24,25]$. One cannot ascertain from these results whether Oguni and Tani [8] as well as Kitsuno et al. [9] synthesized bis(alkylzinc) imides and used them for their investigations.

\section{Supplementary material}

Crystallographic data (excluding structure factors) for the structures of $\mathbf{1}, \mathbf{2}$, and $\mathbf{3}$ have been deposited with the Cambridge Crystallographic Data Centre as supplementary publication no. CCDC 146588 for $\mathbf{1}$, 146589 for 2, and 146590 for 3. Copies of the data can be obtained free of charge on application to The Director, CCDC, 12 Union Road, Cambridge CB2 1EZ, UK (fax: + 44-1123-336-033; e-mail: deposit@ccdc.cam. ac.uk or www: http://www.ccdc.cam.ac.uk).

\section{Acknowledgements}

This work was financially supported by the Deutsche Forschungsgemeinschaft, Bonn, and the Fonds der Chemischen Industrie, Frankfurt/Main. T.B. wishes to express his gratitude to the Fonds der Chemischen Industrie for a Ph.D. scholarship granted.

\section{References}

[1] E. Frankland, Proc. R. Soc. 8 (1856) 502.

[2] E. Frankland, Jahresber. (1867) 419.

[3] M.F. Lappert, P.P. Power, A.R. Sanger, R.C. Srivastava, Metal and Metalloid Amides, Ellis Horwood, Chichester, 1980, pp. $545-566$

[4] (a) A. Haaland, K. Hedberg, P.P. Power, Inorg. Chem. 23 (1984) 1972. (b) P.P. Power, K. Ruhlandt-Senge, S.C. Shoner, Inorg. Chem. 30 (1991) 5013. (c) W.S. Rees, D.M. Green, W. Hesse, Polyhedron 11 (1992) 1697. (d) M.A. Putzer, A. Dashti-Mommertz, B. Neumüller, K. Dehnicke, Z. Anorg. Allg. Chem. 624 (1998) 263. (e) W.S. Rees, O. Just, H. Schumann, R. Weimann, Polyhedron 17 (1998) 1001. (f) H. Schumann, J. Gottfriedsen, S. Dechert, F. Girgsdies, Z. Anorg. Allg. Chem. 626 (2000) 747.

[5] M. Westerhausen, M. Wieneke, W. Schwarz, J. Organomet. Chem. 572 (1999) 249.

[6] M.M. Olmstead, W.J. Grigsby, D.R. Chacon, T. Hascall, P.P. Power, Inorg. Chim. Acta 251 (1996) 273.

[7] M.G. Davidson, D. Elilio, S.L. Less, A. Martín, P.R. Raithby, R. Snaith, D.S. Wright, Organometallics 12 (1993) 1.

[8] (a) H. Tani, N. Oguni, Polym. Lett. 7 (1969) 769. (b) N. Oguni, H. Tani, J. Polym. Sci. 11 (1973) 573.

[9] H. Kitsuno, T. Yasuda, M. Okuyama, Chem. Abstr. 129 (1998) 309674 JP 97-70543 19970307.

[10] T. Hascall, K. Ruhlandt-Senge, P.P. Power, Angew. Chem., Int. Ed. Engl. 33 (1994) 356; Angew. Chem. 106 (1994) 350.

[11] W.J. Grigsby, T. Hascall, J.J. Ellison, M.M. Olmstead, P.P. Power, Inorg. Chem. 35 (1996) 3254.

[12] S. Schulz, A. Voigt, H.W. Roesky, L. Häming, R. Herbst-Irmer, Organometallics 15 (1996) 5252.

[13] (a) D. Gudat, H.M. Schiffner, M. Nieger, D. Stalke, A.J. Blake, H. Grondey, E. Niecke, J. Am. Chem. Soc. 114 (1992) 8857. (b) H.-J. Goetze, B. Bartylla, M. Ismeier, Spectrochim. Acta 49 (1993) 497.

[14] T. Hahn (Hrsg.), International Tables for Crystallography, vol. A, Space Group Symmetry, 2. Aufl., Reidel, Dordrecht, 1984.

[15] SHELXTL PLUS (PC-Version), Siemens Analytical X-ray Instruments, 1989. G.M. Sheldrick, SHELXL-93, Universität Göttingen, Germany, 1993. 
[16] D.T. Cromer, J.B. Mann, Acta Crystallogr., Sect. A 24 (1968) 321.

[17] R.F. Stewart, E.R. Davidson, W.T. Simpson, J. Chem. Phys. 42 (1995) 3175.

[18] M. Westerhausen, M. Wieneke, K. Doderer, W. Schwarz, Z. Naturforsch. 51b (1996) 1439.

[19] M. Wieneke, M. Westerhausen, in: N. Auner, J. Weis (Eds.), Organosilicon Chemistry IV - From Molecules to Materials, Wiley-VCH, Weinheim, 2000, p. 281.

[20] M. Melnik, J. Skoršepa, K. Györyová, C.E. Holloway, J. Organomet. Chem. 503 (1995) 1.
[21] M.G. Davidson, D. Elilio, S.L. Less, A. Martín, P.R. Raithby, R. Snaith, D.S. Wright, Organometallics 12 (1993) 1.

[22] M.A. Putzer, A. Dashti-Mommertz, B. Neumüller, K. Dehnicke, Z. Anorg. Allg. Chem. 624 (1998) 263.

[23] (a) M. Westerhausen, B. Rademacher, W. Schwarz, J. Organomet. Chem. 427 (1992) 275. (b) M. Westerhausen, T. Bollwein, K. Polborn, Z. Naturforsch. 55b (2000) 51 and literature cited therein.

[24] M. Westerhausen, M. Wieneke, W. Schwarz, J. Organomet. Chem. 522 (1996) 137.

[25] M. Westerhausen, B. Rademacher, W. Schwarz, J. Weidlein, S. Henkel, J. Organomet. Chem. 469 (1994) 135. 